\title{
Konflik Kewenangan Pemerintah dan Persatuan Sepakbola Seluruh Indonesia Menyelesaikan Sengketa Pemain Sepakbola
}

\section{Ferry Anggriawan}

Ferry Anggriawan; Fakultas Hukum Universitas Brawijaya Malang; Jl. MT. Haryono 169 Malang; 65145; Indonesia

ART I CLEINFO

Article history:

Received 2018-09-05

Received in revised

2018-10-21

Accepted 2018-12-01

Kata kunci: Konflik Kewenangan, PSSI, Pemain Sepakbola

Profesional

Keywords: Conflicts of Authority, PSSI, Professional Soccer Players
Corresponding Author:

Ferry Anggriawan

E-mail address: fanggriawan1@gmail..com

\section{Abstrak}

Penelitian ini bertujuan untuk mengkaji konflik kewenangan Pemerintah dan PSSI dalam menyelesaikan sengketa pemain sepakbola profesional yang terjadi di luar pertandingan sepakbola. Konflik kewenangan terjadi ketika PSSI menyelesaikan sengketa pemain sepakbola profesional yang tidak sesuai dengan hukum positif di Indonesia. Penelitian ini menghasilkan kesimpulan antara lain; pertama kedudukan hukum kewenangan PSSI ketika menyelesaikan sengketa pemain sepakbola profesional tidak sesuai dengan tujuan hukum, karena tidak memenuhi salah satu unsur yaitu kepastian hukum, mekanisme penyelesaian sengketa yang diterapkan oleh PSSI tidak sesuai dengan doktrin hukum olahraga transnasional yang mengacu kepada FIFA, dan berakibat tidak terciptanya keadilan dan kemanfaatan; kedua dampak jika PSSI menyelesaikan sengketa dengan mengacu pada sistem hukum olahraga transnasional adalah kewenangan PSSI tersebut bertentangan dengan hukum positif di Indonesia, diantaranya Pasal 59 ayat 3 Undang-Undang No 17 Tahun 2013 tentang Organisasi Kemasyarakatan, Pasal 121 ayat 1 dan 2 Peraturan Pemerintah No 16 Tahun 2007 tentang Penyelenggaraan Keolahragaan.

\section{Abstract}

This study aims to examine conflicts of authority of the Government and PSSI in resolving disputes of professional football players that occur outside of football matches. Conflicts of authority occur when PSSI resolves the dispute of professional football players who are inconsistent with positive law in Indonesia. This research resulted in conclusion, among others; the first legal position of PSSI authority when settling the dispute of professional soccer player is not in accordance with the purpose of law, because it does not meet one element of legal certainty, dispute resolution mechanism applied by PSSI not in accordance with the doctrine of transnational sport law that refers to FIFA, justice and benefit; second impact if PSSI resolve the dispute with reference to transnational sports law system is the authority of PSSI is contrary to positive law in Indonesia, among others Article 59 paragraph 3 Law No. 17 of 2013 on Social Organization, Article 121 paragraph 1 and 2 Government Regulation No. 16 Year 2007 on the Implementation of Sports. 


\section{Jurnal Cakrawala Hukum, Volume 9 No. 2 Desember 2018}

ISSN PRINT 2356-4962 ISSN ONINE 2598-6538

\section{Latar Belakang}

Berdasarkan alenia keempat Pembukaan Undang-Undang Dasar Negara Republik Indonesia Tahun 1945; negara berkewajiban melindungi segenap bangsa Indonesia, dan seluruh tumpah darah Indonesia dan memajukan kesejahteraan umum warga negaranya. Upaya memajukan kesejahteraan umum oleh Pemerintah bisa dituangkan melalui perumusan keadilan sosial bagi seluruh rakyat Indonesia dan hal ini bisa diciptakan melalui keserasian kerohaniah dan jasmaniah yang bisa diwujudkan melalui kegiatan olahraga. (Purnadi, 1982)

Salah satu cabang olahraga yang digemari oleh warga negara Indonesia adalah sepakbola. Keolahragaan termasuk sepakbola, telah diatur dalam Undang-Undang No 3 Tahun 2005 tentang Sistem Keolahragaan Nasional dan Peraturan Pemerintah No 16 Tahun 2007 tentang Penyelenggaraan Keolahragaan. Kemenpora diberikan kewenangan dalam pelaksanaan kompetisi sepakbola profesional, hal tersebut telah dituangkan dalam Pasal 13 ayat 1 Undang-Undang No 3 tahun 2005 tentang Sistem Keolahragaan Nasional yang menyatakan sebagai berikut: "Pemerintah mempunyai kewenangan untuk mengatur, membina, mengembangkan, melaksanakan, dan mengawasi penyelenggaraan keolahragaan secara nasional."

Beberapa kewenangan yang telah dikemukakan melalui pasal tersebut merupakan dasar hukum Kemenpora dalam menyelenggarakan kompetisi sepakbola profesional di Indonesia dan menyelesaikan sengketa sepakbola di Indonesia.

Ketika Pemerintah melalui Kemenpora diberikan kewenangan dalam menyelenggarakan kompetisi sepakbola profesional oleh Undang-Undang, tetapi faktanya kompetisi sepak bola profesional di Indonesia bukan diselenggarakan oleh Kemenpora melainkan diselenggarakan oleh Persatuan Sepakbola Seluruh Indonesia selanjutanya disebut PSSI dengan PT Liga Indonesia Baru sebagai operatornya. Perlu diketahui bahwa sepakbola adalah salah satu cabang olahraga yang tidak diciptakan oleh negara. Sepakbola adalah milik komunitas masyarakat dunia yaitu FIFA (Federation International de Football Asociation). FIFA adalah organisasi privat internasional non negara yang mempunyai 208 anggota berupa Asosiasi-asosiasi sepakbola di berbagai negara dan terbagi ke dalam 6 konfederasi, yang telah mengelola sepakbola dunia sejak tahun 1904. FIFA didirikan berdasarkan Code Civil Swiss karena (memang) berkantor di Lausanne, Swiss. Sepakbola mempunyai konstitusi sendiri, regulasi sendiri dan sistem hukum sendiri. Sepakbola mempunyai badan peradilannya sendiri terbebas dari campur tangan pengadilan negara. Ada Komisi Disiplin dan Komisi Banding untuk menegakkan Kode Disiplin Sepakbola, dan berakhir di Court of Arbitration on Sports (CAS). (lex Sportiva, 2017)

PSSI (Persatuan Sepakbola Seluruh Indonesia) adalah anggota organisasi FIFA yang berdomisili di Indonesia mempunyai wewenang dalam mengatur, mengurus dan menyelenggarakan semua kegiatan dan penyelenggaran sepakbola di Indonesia. Perlu diketahui bahwa posisi FIFA dan PSSI bukanlah sebagai state, melainkan mereka adalah civil society, yang diakui eksistensi dan aktuliasinya di Indonesia. Kewenangan yang dimiliki PSSI dalam mengembangkan dan mempromosikan sepakbola nasional telah dijamin oleh induk organisasinya yaitu FIFA, bukan hanya itu PSSI juga diberikan kewenangan untuk menyelesaikan sengketa tanpa ada campur tangan dari Pemerintah.

Konflik yang terjadi adalah ketika PSSI berusaha menyelesaikan sengketa pemain sepakbola di luar pertandingan sepakbola atau di luar the rules of the game yang diatur oleh FIFA. Berikut ini adalah dua permasalahan sengketa pemain sepakbola diluar pertandingan sepakbola yang diselesaikan sendiri oleh PSSI melalui Komite Disiplin PSSI dan PT Liga Indonesia baru. 1) Tersebarnya video 3 pemain Persija Jakarta yaitu Riko Simanjuntak, 
Gunawan Dwi Cahyo, Ahmad Syaifullah dengan bermain gitar ketiga pemain tersebut bernyanyi dengan lirik menghina supporter Persib Bandung yaitu Viking dengan menggunakan kata binatang. (CNN, 2018) Akibat perbuatannya tersebut Komite Disiplin PSSI menghukum yang bersangkutan dengan denda 15 juta setiap pemainnya. (Sport, 2018); 2) Penunggakan gaji pemain PSBI Blitar di Liga 2 selama 2 bulan, yang secara otomatis merugikan hak-hak pemain profesional yang bermain untuk PSBI Blitar (Jatim, 2018). Masalah hak-hak pemain telah diatur dalam Pasal 72 huruf $b$ Regulasi Liga 2 yang menyatakan apabila klub belum memenuhi hak-hak pemain melebihi 2 kali 30 hari kalender, maka klub tersebut akan dikenakan sanksi pengurangan 3 poin (klasemen) dalam kompetisi tersebut. Tetapi dalam faktanya tidak ada pengurangan poin untuk PSBI Blitar hingga kompetisi selesai.

Dari kedua kasus sengketa pemain sepakbola profesional di atas perlu dicermati bahwa semua kejadian terjadi diluar domain the rules of the game. Untuk kasus yang pertama tentang nyanyian rasis ketiga pemain Persija yang mengakibatkan kehormatan dan nama baik supporter Persib Bandung (Viking) tercemar, perbuatan tersebut telah memenuhi unsur tindak pidana yang diatur dalam Pasal 27 ayat (3) Undang-Undang No 11 Tahun 2008 tentang Informasi dan Transaksi Elektronik yang menyatakan sebagai berikut: "Setiap Orang dengan sengaja dan tanpa hak mendistribusikan dan/atau mentransmisikan dan/atau membuat dapat diaksesnya Informasi Elektronik dan/atau Dokumen Elektronik yang memiliki muatan penghinaan dan/atau pencemaran nama baik."

Selanjutnya mengenai sanksi bagi pelaku yang akibat perbuatannya mengandung muatan penghinaan dan/ atau pencemaran nama baik telah diatur dalam Pasal 45 ayat (1) Undang-Undang No 11 tahun 2008 tentang Informasi dan Transaksi Elektronik yang menyatakan sebagai berikut:
"Setiap Orang yang memenuhi unsur sebagaimana dimaksud dalam Pasal 27 ayat (1), ayat (2), ayat (3), atau ayat (4) dipidana dengan pidana penjara paling lama 6 (enam) tahun dan/atau denda paling banyak Rp1.000.000.000,00 (satu miliar rupiah)."

Perbuatan yang dilakukan oleh 3 pemain Persija Jakarta yaitu Riko Simanjuntak, Gunawan Dwi Cahyo dan Ahmad Syaifullah telah memenuhi unsur pidana sesuai dengan ketentuan pasal di atas. Seharusnya perkara ini diselesaikan oleh negara di ranah hukum pidana karena negara juga mempunyai kedaulatan terhadap warga negaranya yang berprofesi sebagai pemain sepakbola profesional. Konflik kewenangan terjadi ketika PSSI menyelesaikan masalah ini dengan sistem hukum PSSI melalui Komite Disiplin yang domain kasusnya terjadi di luar pertandingan sepakbola.

Untuk permasalahan kedua yang terjadi akibat keterlambatan gaji pemain yang dialami oleh pemain PSBI Blitar adalah sebagai berikut: Pertama; PSSI melalui PT Liga Indonesia Baru yang mengacu pada Pasal 72 huruf b Regulasi Liga 2 menyatakan bahwa keterlambatan gaji pemain melebihi 2 bulan akan ada pengurangan poin sejumlah 3 poin. Namun dalam pelaksanaan kompetisi sampai selesai tidak ada pengurangan poin yang dilakukan oleh PT Liga Indonesia Baru terhadap PSBI Blitar. Kedua tentang larangan pemain menyelesaikan sengketa gaji kepada pengadilan di luar yuridiksi PSSI, sesuai dengan Pasal 70 Statuta PSSI yang menyatakan sebagai berikut: 1) PSSI, Anggota, Pemain, Ofisial, serta Agen pemain dan Agen pertandingan tidak diperkenankan mengajukan perselisihan ke Pengadilan Negara dan badan arbitrase lainnya serta alternatif penyeleseian sengketa lainnya, kecuali yang ditentukan dalam Statuta ini dan peraturan-peraturan FIFA. Setiap sengketa harus diajukan kepada yurisdiksi FIFA atau yuridiksi PSSI.

Namun ketika penulis mendapatkan salinan Perjanjian Kontrak Kerja Nomor 32/ Liga 2/ PSBI/ 
4/ 2017 atas nama Moch. Asni Fitiran selaku pemain PSBI dalam Pasal 11 ayat 1 dan 2 menyatakan sebagai berikut: 1 . Setiap perselisihan yang timbul akibat dari perjanjian kontrak kerja ini, kedua belah pihak sepakat untuk menyelesaikannya dengan musyawarah. 2. Apabila terdapat perselisihan tersebut dalam ayat 1 tidak tercapai kata sepakat, maka kedua belah pihak saling setuju untuk menyelesaikannya melalui PSSI atau dengan memilih domisili hukum yang tetap dan umum di Kantor Kepaniteraan Pengadilan Negeri Blitar.

Ada beberapa poin yang perlu dicermati dari salinan Perjanjian Kontrak Kerja tersebut Pertama; perjanjian kontrak pemain sepakbola adalah murni perjanjian kontrak kerja seperti halnya pekerjaan lainnya yang sudah diatur berdasarkan Pasal 1 angka 15 Undang-Undang Nomor 13 Tahun 2003 tentang Ketenagakerjaan disebutkan bahwa yang dimaksud dengan hubungan kerja adalah hubungan antara pengusaha dengan pekerja/buruh berdasarkan perjanjian kerja, yang mempunyai unsur pekerjaan, upah dan perintah.

Perjanjian kontrak kerja yang dilakukan oleh pemain PSBI Blitar yaitu Moch. Asni Fitrian telah memenuhi unsur perjanjian kerja yang sudah diatur dalam Pasal 1 angka 15 Undang-Undang Nomor 13 tahun 2003 tentang Ketenagakerjaan dengan fakta hukum sebagai berikut; adanya hubungan kerja antara H. Herry Noegroho, SE, MH selaku Pihak Pertama yang mempekerjakan Moch Asni Fitrian selaku Pihak Kedua sebagai pekerja berdasarkan Perjanjian Kontrak Kerja Nomor 32/ Liga 2/ PSBI/ 4/ 2017 dengan unsur pekerjaan sebagai pemain sepakbola profesional PSBI Blitar dengan upah yang sudah disepakati bersama dan perintah yang wajib ditaati oleh Pihak kedua sesuai dengan kesepakatan yang tertera dalam Surat perjanjian kontrak kerja tersebut.

Permasalahan selanjutnya berada pada penyelesaian perselisihan antar kedua belah pihak. Dalam Pasal 11 Perjanjian Kontrak Kerja Nomor 32/ Liga 2/ PSBI/ 4/ 2017 disebutkan bahwa kedua belah pihak sepakat apabila perselisihan tersebut tidak menemui kata sepakat maka kedua belah pihak akan menyelesaikan melalui Kantor Kepaniteraan Pengadilan Negeri Blitar.

Jika kita mengacu pada kedudukan hukum PSSI di Indonesia sebagai badan hukum perkumpulan yang sudah disahkan oleh Menteri Kehakiman Republik Indonesia dengan akta pengesahan Nomor: J.A.5/11/ 6 tertanggal 2 Februari 1953, PSSI selain harus tunduk pada Statuta FIFA, Statuta AFC dan Statuta PSSI mereka juga harus tunduk pada hukum positif di Indonesia, karena mereka sudah termasuk subjek hukum di negara ini. Dalam Pasal 59 ayat (3) huruf d Undang-Undang No 17 Tahun 2013 tentang Organisasi Kemasyarakatan disebutkan sebagai berikut: (3) Ormas dilarang: d. melakukan kegiatan yang menjadi tugas danwewenang penegak hukum sesuai denganketentuan peraturan perundang-undangan.

PSSI selaku Organisasi Masyarakat seharusnya tidak diperbolehkan menyelesaikan sengketa yang bukan kewenangannya. Jika dilihat dari fakta hukum yang terjadi saat ini, kewenangan PSSI telah melampaui segi penyelenggaraan sepakbola. Kasus sengketa pemain sepakbola yang mengandung unsur pidana di luar pertandingan sepakbola juga ikut diselesaikan oleh PSSI, bahkan sengketa perselisihan kontrak pemain, PSSI melarang untuk diselesaikan melalui Kantor Kepaniteraan Pengadilan Negeri Blitar.

Kedudukan hukum PSSI sebagai anggota FIFA mengharuskan PSSI harus tunduk pada sistem hukum yang diterapkan oleh FIFA, dan kedudukan hukum PSSI sebagai badan hokum perkumpulan mengharuskan PSSI harus patuh pada hukum positif di Indonesia. Peran PSSI dalam Mengembangkan dan mempromosikan sepakbola secara terus menerus, mengatur dan mengawasinya di seluruh wilayah Negara Kesatuan Republik Indonesia dengan semangat fair play, seharusnya harus diimbangi dengan kepatuhan hukum PSSI sebagai subjek hukum di Negara Kesatuan Republik Indonesia. 


\section{Metode}

Untuk menjawab penelitian ini, digunakan penelitian yuridis normatif. Dengan menggunakan pendekatan perundang-undangan, pendekatan konseptual dan pedekatan historis. Dalam hal ini mengkaji kedudukan hukum kewenanngan PSSI ketika menyelesaikan sengketa pemain sepakbola profesional dalam sistem hukum olahraga nasional dan sistem hukum olahraga transnasional, kemudian mengharmonisasikan kewenangan PSSI dan Pemerintah dalam hal menyelesaikan sengketa pemain sepakbola profesional di luar pertandingan sepakbola.

\section{Pembahasan}

\subsection{Kedudukan Hukum Kewenangan PSSI Dalam Menyelesaikan Sengketa Pemain Sepakbola Profesional Di Luar Pertandingan Sepakbola}

Analisis kedudukan hukum PSSI dalam menyelesaikan sengketa pemain sepakbola profesional akan dibahas melalui 2 sistem hukum yaitu; kedudukan hukum kewenangan PSSI ketika menyelesaikan sengketa pemain sepakbola profesional dalam sistem hukum olahraga transnasional dan kedudukan hukum kewenangan PSSI ketika menyelesaikan sengketa pemain sepakbola profesional dalam sistem hukum olahraga nasional.

Tersebarnya video 3 pemain Persija Jakarta yaitu Riko Simanjuntak, Gunawan Dwi Cahyo, Ahmad Syaifullah dengan bermain gitar ketiga pemain tersebut bernyanyi dengan lirik menghina suporter Persib Bandung yaitu Viking dengan menggunakan kata binatang (CNN, 2018). Akibat perbuatannya tersebut Komisi Disiplin PSSI menghukum yang bersangkutan dengan denda 15 juta setiap pemainnya (Sport, 2018).

Perilaku yang dilakukan dan ditunjukkan oleh ketiga Pemain Persija tersebut dapat merusak integritas dan reputasi sepakbola yang seharusnya dijaga dan diperjuangkan oleh pemain profesional untuk melindungi citra sepakbola nasional. Jika dilihat dari domain kejadian tersebut, ketiga pemain Persija tidak melakukannya pada saat pertandingan, sebelum pertandingan dan setelah pertandinngan. Kejadian tersebut terjadi di salah satu kamar mess Persija dan video itu direkam ketika mereka setelah latihan bukan setelah pertandingan. salah satu badan yang berhak menyatakan bahwa perlakuan tersebut dinyatakan bersalah atau tidak adalah Komite Etik, dan faktanya komite etik menyatakan perbuatan tersebut bertentangan dengan kode etik PSSI dan dinyatakan bersalah. Badan yudisial PSSI yang berhak menghukum anggotanya adalah Komite Disiplin.

Dasar hukum Komite Disiplin PSSI menjatuhkan hukuman terhadap ketiga pemain Persija Jakarta yaitu Riko Simanjuntak, Ahmad Syaifullah, dan Gunawan Dwi Cahyo adalah Pasal 54 Kode Disiplin PSSI yang menyebutkan sebagai berikut: 1. Pemain atau ofisial yang memancing kebencian atau kekerasan diberikan sanksi skors tidak kurang dari 12 (dua belas) bulan dan denda minimal Rp. 75.000.000,- (tujuh puluh lima puluh juta rupiah). 2. Apabila perbuatan sebagaimana diatur dalam ayat (1) di atas dilakukan melalui media massa (seperti melalui media cetak, media sosial, siaran televisi atau radio) baik secara langsung (live) maupun secara tidak langsung atau apabila dilakukan langsung pada saat pertandingan di stadion atau di sekitar stadion, maka sanksi denda yang dijatuhkan minimal sebesar Rp. 300.000.000,- (tiga ratus juta rupiah).

Hukuman terhadap anggota PSSI baik pemain atau official yang melakukan diskriminasi dengan cara memancing kebencian atau kekerasan telah diatur dalam Pasal tersebut. Kalkulasi hukuman dan jumlah denda telah disebutkan denda minimal yang harus dibayarkan bagi anggota PSSI yang dinyatakan bersalah oleh Komite Etik PSSI.

Fakta hukum yang terjadi terkait kasus ini adalah ketiga pemain Persija yaitu Riko Simanjuntak, 
Ahmad Syaifullah dan Gunawan Dwi Cahyo masing-masing diberikan hukuman dengan membayar denda sebesar 15.000.000,- (Lima Belas Juta Rupiah) untuk setiap pemain. Hukuman yang diberikan oleh Komite Disiplin tidak sesuai dengan Pasal 54 Kode Disiplin PSSI yang seharusnya dijadikan dasar hukum untuk memberikan hukuman terhadap ketiga pemain Persija yang dinyatakan bersalah oleh Komite Etik PSSI.

Ada beberapa faktor yang harus dipenuhi oleh PSSI agar tercapai tujuan hukum ketika menyelesaikan sengketa ketiga pemain Persija Jakarta yaitu; kepastian hukum, keadilan dan kemanfaatan, berikut ini akan dijelaskan tindakan hukum yang telah dilakukan oleh PSSI dan bagaimana korelasinya dengan teori tujuan hukum, yaitu kepastian hukum, keadilan dan kemanfaatan.

Kepastian hukum sangat erat kaitannya dengan asas legalitas, yang dijadikan dasar hukum untuk bertindak dan mengungkapkan dengan jelas, bahwa asas legalitas merupakan suatu produk masyarakat yang terikat ruang dan waktu (PAF, 1997). Statuta PSSI, Kode Disiplin PSSI dan Peraturan Organisasi PSSI Tahun 2009 tentang Kode Etik dan Fair play merupakan asas legalitas PSSI dalam menyelesaikan sengketa ketiga pemain Persija tersebut. Mekanisme penyelesaian yang dilakukan oleh PSSI melalui Komite Etik PSSI hingga Komite Disiplin PSSI sebagai Badan Yudisial PSSI yang diberikan kewenangan untuk menyelsaikan sengketa tersebut telah sesuai dengan dasar hukum yang telah diterapkan.

Salah satu poin yang belum terpenuhi akan kepastian hukum adalah terkait hukuman yang dijatuhkan oleh PSSI terhadap ketiga pemain Persija tidak sesuai dengan Pasal 54 Kode Disiplin PSSI yang menyatakan minimal denda terhadap pemain yang melakukan tindakan diskriminasi terhadap suporter adalah minimal 300.000.000,- (Tiga Ratus Jutaa Rupiah), tetapi faktanya Komite Disiplin PSSI memberikan hukuman hanya 15.000.000,- (Lima Belas Juta Rupiah) terhadap setiap pemain Persija yang tersangkut masalah ini. Keberadaan Pasal 54 Kode Disiplin PSSI yang diharapkan dijadikan dasar akan kepastian hukum oleh PSSI dan anggota PSSI untuk diterapkan oleh Komite Disiplin PSSI tidak diterapkan (Ahmad, 2010). Komite Disiplin PSSI telah melakukan kewenangan yang tidak sesuai dengan Pasal 54 Kode Disiplin PSSI yang mengakibatkan tidak terpenuhinya salah satu unsur dari tujuan hukum yaitu kepastian hukum.

Kasus selanjutnya adalah penunggakan gaji pemain PSBI Blitar di Liga 2 selama 2 bulan, yang secara otomatis merugikan hak-hak pemain profesional yang bermain untuk PSBI Blitar (Jatim, 2018). Masalah hak-hak pemain telah diatur dalam Pasal 72 huruf b Regulasi Liga 2 yang menyatakan apabila klub belum memenuhi hak-hak pemain melebihi 2 kali 30 hari kalender, maka klub tersebut akan dikenakan sanksi pengurangan 3 poin (klasemen) dalam kompetisi tersebut. Tetapi dalam faktanya tidak ada pengurangan poin untuk PSBI Blitar hingga kompetisi selesai.

Kedudukan hukum yang akan dianalisis dalam permasalahan ini adalah dasar hukum kewenangan PT Liga Indonesia Baru yaitu Pasal 72 huruf b Regulasi Liga 2 yang menyebutkan apabila klub belum memenuhi hak-hak pemain melebihi 2 kali 30 hari kalender, maka klub tersebut akan dikenakan sanksi pengurangan 3 poin (klasemen) dalam kompetisi tersebut. Alasan kenapa penulis menjadikan dasar hukum tersebut untuk dianalisis kedudukan hukumnya dalam sistem hukum olahraga transnasional adalah; 1) tidak adanya tindakan hukum yang dilakukan oleh PSSI dan PT Liga Indonesia Baru terkait adanya kasus tunggakan gaji pemain PSBI, 2) pihak yang bersengketa dalam hal ini Moh Asni dan Manajemen PSBI tidak melakukan langkah hukum untuk menyelesaikannya, baik kepada PSSI dan Kantor Kepaniteraan Pengadilan Negeri Blitar.

Pasal 72 huruf b Regulasi Liga 2 yang mengatur tentang mekanisme penyelesaian sengketa gaji pemain dengan klub dan pelatih dengan klub, 
memberikan hukuman pengurangan poin di kompetisi domestik terhadap klub yang terlambat memberikan gaji terhadap pemain. Analisis kedudukan hukum Pasal tersebut tidak sesuai dengan tujuan hukum karena Regulasi Liga 2 tidak mengakui adanya Dispute Resolution Chamber salah satu lembaga tertinggi sengketa kontrak kerja pemain dengan klub yang diterapkan oleh FIFA dan tidak diterapkannya Pasal 72 huruf b Regulasi Liga 2 membuat tujuan hukum kewenangan PSSI melalui Pasal 72 huruf b Regulasi Liga 2 tidak sesuai dengan tujuan hukum karena tidak memenuhi unsur kepastian hukum yang berakibat tidak terciptanya keadilan dan kemanfaatan dari hukum tersebut (Boy, 2012).

Dalam sistem hukum olahraga nasional tindakan hukum PSSI dalam menyelesaikan sengketa pemain sepakbola profesional seperti yang dijelaskan di atas tidak sesuai dengan mekanisme penyelesaian sengketa pemain sepakbola profesional dalam sistem hukum olahraga nasional yang mengacu pada Pasal 121 ayat 1dan 2 Peraturan Pemerintah No 16 Tahun 2007 yang menyatakan pihak yang berwenang memberikan sanksi atas sengketa di luar pertandingan sepakbola adalah Kemenpora, Gubernur, Walikota dan Bupati. Sehingga kedudukan hukum kewenangan PSSI dalam menyelesaikan sengketa pemain sepakbola profesional di luar pertandingan sepakbola adalah tidak sesuai dengan tujuan hukum penyelesaian sengketa tersebut karena tidak memenuhi unsur kepastian hukum dalam sistem hukum olahraga nasional.

\subsection{Harmonisasi Kewenangan Pemerintah dan PSSI dalam Menyelesaikan Sengketa Pemain Sepakbola Profesional di Luar Pertandingan Sepakbola}

Beberapa hal yang akan diharmonisasikan pada bagian ini adalah; Harmonisasi Pasal 59 ayat 3 Undang-Undang No 17 Tahun 2003 tentang Organisasi Masyarakat dengan Pasal 54 Kode
Disiplin PSSI, harmonisasi pengaturan batasan ruang dan waktu penyelesaian sengketa olahraga antara Kemenpora dan PSSI, harmonisasi pengaturan hak pemain sepakbola profesional antara Kemenpora dan PSSI, dan harmonisasi kewenangan antara Pemerintah dan PSSI dalam menyelesaikan sengketa pemain sepakbola profesional di luar pertandingan sepakbola.

Harmonisasi Pasal 54 Kode Disiplin PSSI dengan Pasal 59 ayat 3 Undang-Undang No 17 Tahun 2003 tentang Organisasi Masyarakat, dapat dilakukan oleh Kemenpora melalui pengawasan terhadap PSSI dengan cara; memberikan payung hukum kepada PSSI untuk menyelesaikan sengketa pemain sepakbola profesional, yang sesuai dengan peraturan perundang-undangan dan sesuai dengan nilai-nilai filosofis dalam sepakbola. Tujuannya sampai batas mana kewenangan PSSI dalam menyelesaikan sengketa pemain sepakbola diperbolehkan. Mengingat penghinaan, merupakan suatu tindakan yang mencederai nilai filosofis dalam sepakbola yaitu respect dan tindakan penghinaan juga termasuk dalam delik pidana di Indonesia (Jazim, 2011).

Harmonisasi pengaturan batasan ruang dan waktu penyelesaian sengketa olahraga antara Kemenpora dan PSSI dapat dilakukan oleh Kemenpora dengan mereformulasi Pasal 88 Undang-Undang No 3 Tahun 2005 tentang Sistem Keolahragaan Nasional dengan memberikan penjelasan mengenai batasan ruang dan waktu mengenai sengketa keolahragaan dalam sepakbola dengan mengacu Pasal 5 Kode Disiplin PSSI yang mengatur batasan ruang dan waktu pada pertandingan sepakbola. Penyelesaian sengketa keolahragaan sangat bergantung pada batasan ruang dan waktu apakah sengketa tersebut termasuk sengketa olahraga atau bukan sengketa olahraga.

Harmonisasi pengaturan hak pemain sepakbola profesional dapat dilakukan Kemenpora dengan cara memberikan landasan hukum kepada PSSI untuk menyelesaikan sengketa gaji pemain 
dengan klub, mengingat sengketa gaji pemain sepakbola profesional juga bisa diselesaikan melalui sistem hukum olahraga transnasional, melalui PT Liga Indonesia Baru, NDRC dan DRC.

Harmonisasi kewenangan PSSI dengan Pemerintah dalam hal penyelesaian Sengketa pemain sepakbola profesional terkait kasus penghinaan ketiga pemain Persija kepada supporter Persib dapat dilakukan dengan: a) Memberikan landasan hukum kewenangan kepada PSSI serta mengakui Badan Yudisial yang diterapkan oleh PSSI untuk memberikan sanksi kepada ketiga pemain Persija, karena perbuatan tersebut dapat menimbulkan efek permusuhan antara supporter Persib dan Persija, yang tidak sesuai dengan spirit dalam olahraga yaitu respect; b) Memberikan peluang kepada supporter Persib untuk melapor kepada pihak Kepolisian. Sesuai dengan batasan ruang dan waktu terkait pertandingan, kejadian tersebut terjadi di luar batas pertandingan yang di atur oleh PSSI, jadi hukum positif berhak untuk masuk dalam kasus ini; c) Jika kasus tersebut sudah masuk dalam hukum pidana, maka tidak menggugurkan hukuman yang diberikan PSSI terhadap ketiga pemain Persija tersebut. Dua sistem hukum berjalan (saling bersinergi). Hukuman dari PSSI berupa denda 15.000.000,- untuk setiap pemain adalah konsekuensi dia sebagai pemain sepakbola profesional yang melakukan tindakan yang tidak sesuai dengan etika pemain sepakbola yang mengakibatkan tercorengnya integritas dan reputasi sepakbola di Indonesia. Selain hukuman dari PSSI, hukuman dari hukum positif di Indonesia juga berhak untuk diterapkan karena kejadian tersebut terjadi bukan di luar ketentuan pertandingan.

Harmonisasi kewenangan Pemerintah dengan PSSI untuk menyelesaikan sengketa kontrak kerja yang dialami oleh PSBI Blitar dapat dilakukan dengan: a) Memberikan landasan hukum kepada PSSI akan adanya mekanisme penyelesaian sengketa kontrak kerja pemain sepakbola profesional melalui PSSI yang diterapkan oleh PT Liga Indo- nesia Baru yang berkelanjutan mulai dari PT Liga Indonesia Baru, NDRC hingga DRC; b) Memberikan landasan hukum kepada pemain PSBI Blitar untuk membawa kasus keterlambatan gaji ke Kantor Kepaniteraan Blitar. Mengingat kasus sengketa kontrak kerja tidak terjadi pada batas dan waktu pertandingan yang diatur oleh PSSI. Dasar hukum selanjutnya adalah Pasal 11 ayat 2 Perjanjian Kontrak Kerja Nomor 32/ Liga 2/ PSBI/ IV/ 2017 menyatakan bahwa kedua belah pihak sepakat apabila dalam hal perselisihan tidak tercapai kata sepakat, maka keduanya saling setuju untuk menyelesaikan sengketa di Kantor Kepaniteraan Blitar; c) Dua mekanisme penyelesaian sengketa kontrak kerja yang disebutkan di atas bertujuan untuk dijadikan pilihan oleh pemain sepakbola profesional ketika akan menyelesaikan sengketa kontrak kerja. Penyelesaian sengketa pemain PSBI Blitar melalui PSSI merupakan wadah dan konseskuensi yang dapat dipakai oleh pemain PSBI Blitar karena berprofesi sebagai pemain sepakbola. Tetapi ketika pemain PSBI Blitar membawa kasus ini ke Kantor Kepaniteraan Blitar juga bukan suatu tindakan yang ilegal, karena pemain PSBI Blitar merupakan warga negara Indonesia yang dilindungi haknya oleh negara, melalui hukum positif di Indonesia.

\section{Simpulan}

Berdasarkan hasil dan pembahasan diatas, peneliti menarik beberapa kesimpulan yakni bahwa, kedudukan hukum kewenangan PSSI untuk menerapkan Pasal 72 huruf b Regulasi Liga 2 sebagai dasar hukum ketika menyelesaikan sengketa kontrak kerja pemain PSBI Blitar tidak sesuai dengan sistem hukum yang diterapkan oleh FIFA, yang berakibat tidak adanya akses bagi pemain untuk mengajukan perkara tersebut ke Dispute Resolution Chamber ketika hak pemain belum dipenuhi oleh klub. Mekanisme penyelesaian sengketa kontrak kerja pemain sepakbola profesional yang diterapkan oleh PSSI tidak sesuai dengan 
tujuan hukum, karena tidak memenuhi unsur kepastian hukum, yang berakibat tidak terciptanya keadilan dan kemanfaatan bagi PSSI dan pemain sepakbola profesional di Indonesia. Selanjutnya kedudukan hukum kewenangan PSSI ketika memberikan sanksi berupa denda kepada ketiga pemain Persija jakarta akibat aksi penghinaan terhadap supporter Persib dengan nominal denda Rp. 15.000.000,- untuk setiap pemainnya, belum bisa dikatakan sebagai tujuan hukum, karena tidak memenuhi salah satu kriteria yang harus dipenuhi dalam tujuan hukum yaitu kepastian hukum.

Sistem olahraga nasional tindakan hukum yang dilakukan PSSI dalam menyelesaikan sengketa di atas adalah bertentangan dengan hukum positif di Indonesia. Keberadaan sistem hukum olahraga transnasional yang diterapkan oleh FIFA dan PSSI adalah keniscayaan yang harus diakui oleh Pemerintah, terkait eksistensi dan aktualisasinya di Indonesia. Perlu adanya harmonisasi antara sistem hukum olahraga transnasional yang diterapkan oleh PSSI dan sistem hukum olahraga nasional yang diterapkan oleh Kemenpora. Beberapa hal yang perlu diharmonisasikan adalah; (1) diberikannya landasan hukum PSSI oleh kemenpora dalam menyelesaikan sengketa pemain sepakbola profesional, (2) reformulasi Pasal Pasal 88 Undang-Undang No 3 Tahun 2005 tentang Sistem Keolahragaan Nasional untuk mengatur kembali makna dari sengketa keolahragaan, dengan mengacu pada konsep pertandingan yang diterapkan oleh PSSI, (3) memberikan pengarahan kepada pemain sepakbola profesional bahwa sengketa kontrak kerja juga bisa diselesaikan melalui Pengadilan
Negeri tanpa harus melarang untuk menyelesaikan melalui mekanisme yang diterapkan oleh PSSI.

\section{Daftar pustaka}

Rifai, Ahmad. 2010. Penemuan Hukum oleh Hakim (Dalam Perspektif Hukum Progresif). Jakarta. Sinar Grafika.

Nurdin, Boy. 2012. Kedudukan dan Fungsi Hakim dalam Penegakan Hukum di Indonesia. Bandung. Alumni.

Hamidi, Jazim dan Mustofa Lutfi. 2011. Dekonstruksi Hukum Pengawasan Pemerintah Daerah (The Turning Point of Local Autonomy). Malang. UB Press.

Lamintang, P.A.F. 1997. Dasar-Dasar Hukum Pidana Indonesia. Bandung Citra Aditya Bhakti.

Purbacaraka, Purnadi dan Soerjono Soekanto. 1982. Renungan Tentang Filsafat Hukum. Jakarta. Rajawali.

Undang-Undang Dasar Negara Republik Indonesia Tahun 194510 Agustus 2002 Majelis Permusyawaratan Rakyat Republik Indonesia 2002.

Undang-Undang No 3 tahun 2005 tentang Sistem Keolahragaan Nasional Lembaran Negara Republik Indonesia Tahun 2005 Nomor 89.

Peraturan Pemerintah No 16 Tahun 2007 tentang Penyelenggaraan KeolahragaanLembaran Negara Republik Indonesia Nomor 35.

Undang-Undang No 11 Tahun 2008 tentang Informasi dan Transaksi Elektronik Lembaran Negara Republik Indonesia Nomor 58.

Undang-Undang Nomor 13 Tahun 2003 tentang Ketenagakerjaan Lembaran Negara Republik Indonesia Nomor 39.

Undang-Undang No 17 Tahun 2013 tentang Organisasi Kemasyarakatan Lembaran Negara Republik Indonesia Nomor 116. 